\title{
THE DIFFERENCES BETWEEN DEPRESSION LEVEL BEFORE AND AFTER BEING GIVEN LOGOTHERAPY IN CANCER CLIENTS AT KEN SARAS HOSPITAL SEMARANG REGENCY
}

\author{
Abdul Wakhid ${ }^{1}$, Shofhatun Nadhiyat ${ }^{2}$, Sukarno $^{1}$, Dewi Rosnita ${ }^{1}$ \\ ${ }^{1}$ Lecturer of Nursing, Faculty of Nursing, NgudiWaluyo University \\ ${ }^{2}$ Nurse Staff, Ken Saras Hospital \\ abdul.wakhid2010@gmail.com
}

\begin{abstract}
ABSTRAK
Cancer is one of the most feared diseases that cause death. The most common psychological problem found in cancer clients is depression which can affect the treatment, extend the hospitalization time, decreases the therapeutic process, and client's survival. To overcome the problem on the client, nursing intervention can be given in the form of logotherapy. The purpose of this study is to determine the differences between depression levels before and after logotherapy in cancer client at Ken Saras Hospital, Semarang Regency. This research design used pre-experiment with one group pre-posttest design. The population of this study was cancer patients at Ken Saras hospital as many as 22 respondents by using purposive sampling technique and data collecting tool used Back Depression Inventory. Data analysis used t-test dependent test. The results show that the depression level of cancer clients before logotherapy is mostly in moderate category $(86,4 \%)$, the depression level of cancer clients after logotherapy is mostly in mood disorder $(63,6 \%)$. There are differences between depression levels before and after logotherapy of cancer client at Ken Saras Hospital, Semarang Regency, with $\mathrm{p}$ value $(0,000)<\alpha(0,05)$. Ken Saras hospital should utilize logotherapy as a complementary therapy to support the psychological side of cancer patients so that the healing process can run optimally.
\end{abstract}

Keywords: Logotherapy, Depression Level, Cancer

\section{PRELIMINARY}

The phenomenon of cancer sufferers has experienced a significant increase every year in various parts of the world. GLOBOCAN (International Agency for Research on Cancer / IARC) data revealed that in 2012 there were $14,067,894$ new cases of cancer and 8,201,575 deaths due to cancer worldwide. Whereas the national number of the prevalence of cancer in the population of all ages in Indonesia in 2013 was $1.4 \%$ or estimated at 347,792 people. Yogyakarta Special Region Province has the highest prevalence rate for cancer, which is 4.1\%. Whereas Central Java and East Java are the provinces with the highest number of cancer sufferers, namely 68,638 people $(2.1 \%)$ and 61,230 people $(1.6 \%)$.

According to the Ministry of Health of the Republic of Indonesia (2015), cancer is a disease that arises due to abnormal cell growth, cells that turn into cancer cells, whereas tumor is condition where abnormal cell growth forms a lesion or in many cases forms a lump in body. Tumor is divided into two, namely benign tumor and malignant tumor. The most common psychological problems found in cancer clients are anxiety and depression, anxiety and depression experienced by cancer clients not only affect the quality of life but also have an impact on the treatment, prolong the hospitalization period, and have a negative effect on the diagnosis and survival of the client (Aziz 1996; in Mukwanto et al., 2010). People who are diagnosed with severe diseases such as cancer, coronary heart disease, diabetes are very often accompanied by the appearance of depression (Yoseph, 2014).

Depression is a period of disruption of individual function related to the nature of feelings and accompanying symptoms, including changes in sleep patterns and appetite, psychomotor, concentration, fatigue, despair and helplessness, and suicide (Kaplan, 2010). Depression is a significant contributor to the global burden of psychological distress and affects people in all communities around the world (WHO, 2012). Depression is a form of mental disorder in the nature of feeling (affective, mood) which is characterized by moodiness, sadness, lethargy, loss of passion, no enthusiasm, and feeling helpless, feeling guilty or sinful, useless and hopeless (Iyus Y, 2007). Diagnosis of depression is made if for 2 weeks the client shows symptoms of anorexia, 
fatigue, weight loss and insomnia. In addition the client mention feelings of sadness, loss of interest in everything, moody, hopeless, feeling wasted and worthless (Ismail, 2010). Clients who experience depression will have an impact on the reduction of the therapeutic process, to overcome the problems in the client can be given nursing intervention in the form of logotherapy (Ameli and Dattilio, 2013).

Logotherapy therapy can be used to reduce anxiety in breast cancer patients conducted for eight meetings (Golzan, et., Al, 2015). Logotherapy makes the clients aware of their responsibilities and their choices. This therapy can be given to clients with terminal disease, chronic diseases, posttraumatic distress syndrome, alcohol dependence, grief, depression, personality disorders, obsessive disorder and phobias (Bastaman, 2007). The administration of logotherapy therapy for one hour per week for one month is effective in reducing the level of depression and increasing the meaning of life in adolescents (Robatmili, 2014).

Based on the results of a preliminary study conducted by the researchers on May 3, 2017, there were 63 cancer patients in the oncology polyclinic. Data were also obtained by conducting interviews and observations of 10 clients with cancer at theOncology Polyclinic of Ken SarasHospita. There were three clients who were included in the category of major depression which was marked by their statement that expressed feelings of sadness, despair, complaining of being unable to sleep, feeling happier to be alone in the room, do not have the enthusiasm to undergo treatment, lazy to eat, lose weight more than $1 \mathrm{~kg}$ in one month, diarrhea, often pounding, the client looks moody. Six clients were in the moderate depression category, they said that they were sad about their condition, they could not sleep, decreased appetite, weight loss, looked sluggish. One client was in the category of mild depression, the client seemed calm, she felt thatshe had disappointed the family, realized that she was sick, tried to keep on doing activities, decreased appetite, losing weight $1 \mathrm{~kg}$, sometimes restless.

\section{METHODS}

The method used in this study was preexperiment with pre-posttest design that has been carried out in one group (one group prepost test design). This research was conducted at Oncology Plyclinic of Ken Saras HospitalSemarang Regency on October 23 to November 25, 2017. The population in this study were cancer patients who came to Ken Saras Hospital Semarang oncology polyclinic with a sample of 22 respondents who were taken by using purposive sampling technique. Data collection tools used Back Depression Inventory (BDI). Shapiro Wilk test results obtained $\mathrm{p}$ value greater than 0.05 , it means that the data is normally distributed and bivariate analysis was done by paired t test analysis.

\section{RESULT}

Characteristics of Cancer Clients presented in the following table.

Table 1.

Characteristics of Cancer Clients at Ken Saras Hospital Semarang Regency

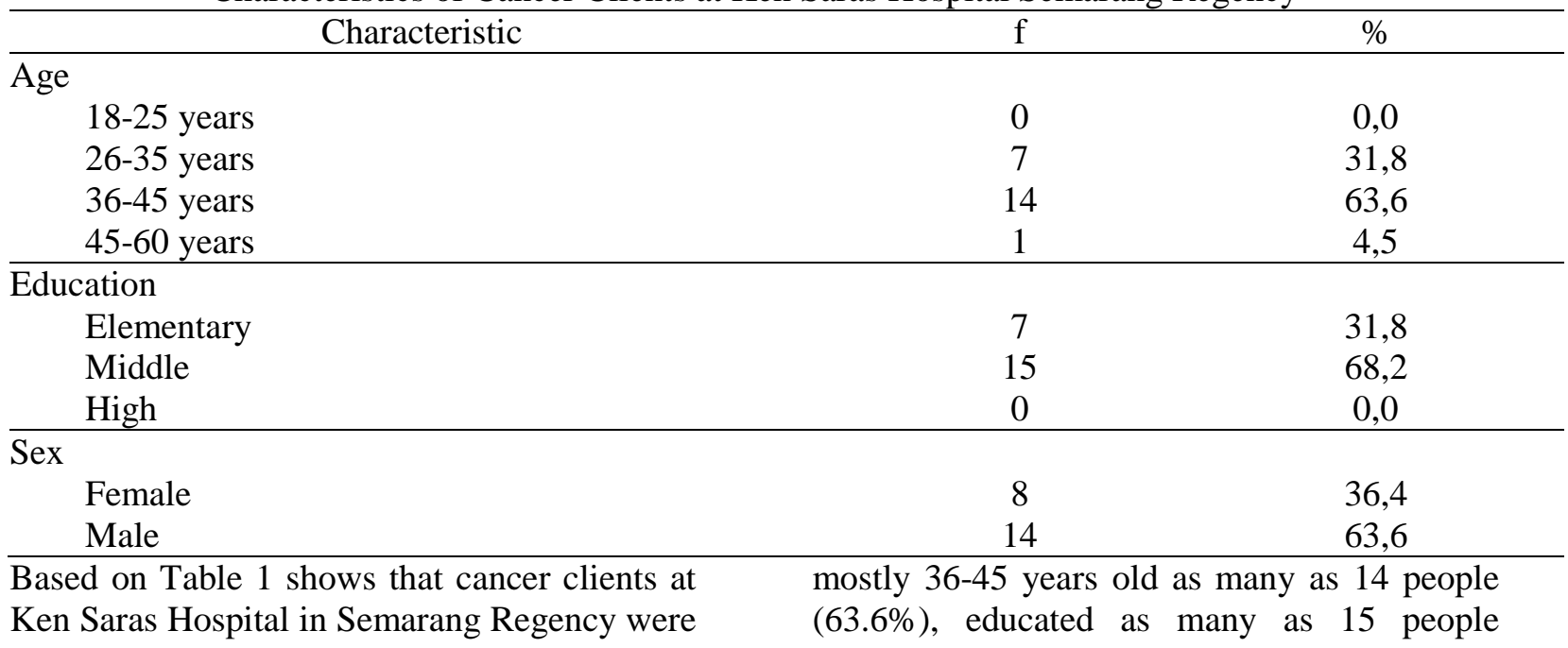


(68.2\%) and male as many as 14 people

$(63.6 \%)$

2. Description of Depression Levels in Cancer Clients before Logotherapy

Table 2.

Description of Depression Levels in Cancer Clients before Logotherapy

\begin{tabular}{lcc}
\hline \multicolumn{1}{c}{ Level ofdepresi } & $\mathrm{f}$ & $\%$ \\
\hline Normal & 0 & 0,0 \\
Mood disorder & 0 & 0,0 \\
Clinical Depression border & 3 & 13,6 \\
Medium Depression & 19 & 86,4 \\
Severe Depression & 0 & 0,0
\end{tabular}

Based on Table 2 shows that the level of depression in cancer clients before logotherapy at Ken Saras Hospital in Semarang Regency is

mostly in moderate depression as many as 19 people $(86.4 \%)$.

\section{Description of Depression Levels in Cancer Clients after Logotherapy}

Table 3.

Description of Depression Levels in Cancer Clients after Logotherapy

\begin{tabular}{lcc}
\hline \multicolumn{1}{c}{ Level ofdepresi } & $\mathrm{f}$ & $\%$ \\
\hline Normal & 7 & 31,8 \\
Mood disorder & 14 & 63,6 \\
Clinical depression border & 1 & 4,5 \\
Medium depression & 0 & 0,0 \\
Severe depression & 0 & 0,0
\end{tabular}

Based on table 3 shows that the level of border as many as 1 person (4.5\%), clients depression in cancer clients at Ken with mood disorder as many as 14 people SarasHospital Semarang Regency after (63.6\%), and in normal conditionas many as 7 logotherapy for 45 minutes, as many as 4 people (31.8\%). meetings were: client with clinical depression

4. Differences between Depression Levels Before and After Logotherapy in Cancer Clients

Table 4.

Differences between Depression Levels Before and After Logotherapy in Cancer Clients

\begin{tabular}{lcccc}
\hline Depresi & Mean & SD & t & $p$-value \\
\hline Pretest & 24,4 & 3,5 & 14,2 & 0,000 \\
Postest & 11,3 & 3,3 & & \\
\hline
\end{tabular}

Based on Table 4 it can be seen that from 22 cancer clients at Ken Saras Hospital Semarang Regencyt the average level of depression before logotherapy is 24,4545 , while the average level of depression after logotherapy is 11,3182. Based on t-test dependent test also shows that $\mathrm{p}$ value $(0,000)<\alpha(0,05)$, so it can be concluded that there is differencesin the level of depression before and after logotherapy for 45 minutes as many as 4 meetingsin cancer clienst at KenSarasHospital Semarang Regency.

\section{DISCUSSION}

1. The Description of Depression Levels in Cancer Clients Before Logotherapy at Ken Saras Hospital Semarang Regency
The results show that the level of depression in cancer clients before logotherapy at Ken Saras Hospital Semarang Regency who experienced moderate depression as many as 19 people (86.4\%), which was indicated by their anxiety when they were old and unattractive $(40,9 \%)$, forcing themselves to do something (50.0\%) decreased appetite (59.1\%).

The result of this study was supported by the research of Suwistianisa (2015) about the factors that influence the level of depression in cancer patients who were treated atArifinAchmad Regional Hospital, Riau Province. The results of univariate analysis showed that the majority of respondents experienced moderate depression as many as 
23 respondents (38.3\%). Nasution's (2010) study showed the characteristics of cancer patients who were hospitalized atDr.Pirngadi Regional Hospital Medan with $49.7 \%$ higheducation. The results of the study showed that respondents who had cancer were partly educated.

This study shows that respondents who experience depression are occurring in clients with higher education (high school, vocational high school) as many as 13 people $(68.4 \%)$. The level of education (and socioeconomic status in general) is not a direct cause of biological effects for disease, these effects are mediated by various risk factors that can trigger the occurrence of disease (eg smoking status, BMI, physical activity). Individuals with higher education tend to take precautions, change behavior for healthy living and use health services properly.

\section{Description of Depression Level in Cancer Clients After Logotherapy at Ken Saras Hospital Semarang Regency}

The results showed that the level of depression in cancer clients at Ken Saras Hospital Semarang Regency after logotherapy with mood disorder as many as 14 people $(63.6 \%)$ indicated by their satisfaction with everything as usual $(54.5 \%)$, still happy to hang out with other people $(68.2 \%)$ and do not feel worse than usual $(68.2 \%)$. One way to reduce pressure in life is communication. Communication is very important for family closeness, knowing problems, responding to non-verbal roles and getting to know the problems in each individual. A good communication process is expected to form a good communication pattern in the family (Siboro, 2012). Communication patterns in the family have a major influence on individual members. Individualization, learning about others, developing and maintaining self-esteem and being able to make choices, all depend on the information that passes through family members (Priyanto, 2009).

Functional communication patterns are more than dysfunctional communication patterns. This means that in families with cancer there is a functional interaction, giving each other a response to family members, can fulfill the functions of a family. According to Friedman (1998) in Barmawi (2009), functional communication patterns can be an indicator of the implementation of family functions to anticipate the pressures and problems that must be faced by cancer patients in the aging process so that cancer patients do not experience depression.

Communication in a healthy family is a very dynamic two-way process. Messages are not only sent and received by a recipient and sender. However, the dynamic nature of this communication creates complex and unpredictable functional interactions. Even in the healthiest family, communication is often tenuous and problematic. In functional families, it has been noted that feelings from family members are permissible expressions (Siboro, 2012). Cancer sufferers who get support from their families will show better physical and mental health conditions (Dani, 2012).

According to Jhonson (1981), our identityis formed through communication with others. Communication has a role as a means of forming mental health. Excellent communication quality, especially to people who are very influential in life will be able to create quality mental health including reducing anxiety, stress and depression. On the other hand, if the communication process that is carried out encounters various obstacles or problems, of course this will also have a direct impact on the quality of mental health, namely anxiety, frustration, depression (Arwani, 2008).

\section{Differences between Depression Level Before and After Logotherapy for Cancer Clients at KenSaras Hospital Semarang Regency}

Based on the t-test dependent test shows that $\mathrm{p}$ value $(0,000)<\alpha(0,05)$, so it can be concluded that there are differences in the level of depression before and after logotherapy performed on cancer clients at Ken Saras Hospital Semarang Regency. Logotherapy implementation consists of 4 sessions, for 45 minutes in one meeting where the principle of meaning in life is in session 3 . The core of the third session of Logotherapy is that individuals explore their own experiences of an unpleasant condition, how they feel at that time, how to overcome them and how is the current feeling and what the meaning obtained from thatmoment. This is certainly very helpful for the client to know and realize the best behavior that must be done to overcome the situation 
that eventually the client is protected from depression due to the illness.

The results showed that from 22 cancer clients at Ken Saras Hospital Semarang Regency, the lowest level of depression before logotherapy was 19.0 and the highest was 30.0 with an average of 24.45 and a standard deviation of 3.50, which was categorized as moderate depression. Cancer clients at Ken Saras Hospital Semarang Regency, the lowest rate of depression after logotherapy was 6.0 and the highest was 20.0 with an average of 11.32 and a standard deviation of 3.37 , which was included in mood disorder category.

Based on these data showed a decrease in the level of depression of cancer clients at Ken Saras Hospital Semarang Regency before and after being given logotherapy with an average difference of 13,13636. The provision of logotherapy is very meaningful because by discovering the meaning of their life the clients will be more able to accept the conditions experienced so that it can suppress anxiety,useless feeling, the feeling of burdening other people or family, disturbed sleep, no appetite

This is in accordance with the statement of Savoline and Granello (2002) in Lewiss (2010) describing logotherapy as a psychotherapy that aims to achieve meaningful life by understanding its condition both physically and spiritually by motivating that every human being has the potential to live meaningfully.

According to Frankl (2008), signs and symptoms that can be found in individuals who do not have the meaning of life are feelings of emptiness, sadness, lack of purpose in life, apathy, feeling useless and feeling bored. In cancer patients who experience depression also found feelings of sadness, anxiety, experiencing sleep disturbances, despair, helplessness, loss of interest, lack of enthusiasm, laziness to do activities resulting in a decrease in meaning and quality of life. Those are signs of depression symptoms.

In the process of adaptation to the disease, cancer clients experience many changes in their lives, such as loss, decreased health conditions, treatment, changing roles, feeling useless, feeling burdened to other people or families, disturbed sleep, no appetite are signs and symptoms of depression. Through Logotherapy the clientsare helped to find the meaning of their life so that they can survive in life and improve the quality of their life (Videbeck, 2008). Logotherapy can help to overcome depression problems (Blair, 2009).

Logotherapy therapy can be used to reduce anxiety in cancer patients conducted four eight meetings (Golzan, et., Al, 2015). Logotherapy makes the clients aware of their responsibilities and choices for them. This therapy can be given to clients with terminal disease, chronic diseases, posttraumatic distress syndrome, alcohol dependence, grief, depression, personality disorders, obsessive disorder and phobias (Bastaman, 2009).

The ability to interpret events in life is a part that greatly affects a person's life. After therapy with logotherapy, a person will be able to interpret life and have commitment to his life. A person who is not able to interpret the experienced sick condition will feel that the pain that he feels causes him to be meaningless, useless and not motivated to try to recover from his illness. People in a sick condition must have a goal to be able to recover, because it will encouragesthem to be adaptive to changes that occur during illness, but also to be more patient in facing the condition (Frankl, 2009).

This is in line with the research conducted by Trisnapati (2012) at Dharma BaktiWredha Nursing Home in Surakarta. It was found that the meaningfulness of life training was effective in reducing the level of depression in the elderly by $77.78 \%$. This meaningful life training can be said to help respondents in dealing with the level of depression. Stress has a very close relationship to the occurrence of depression. A person experiences depression due to not being able to respond or adapt to stressors properly. Prolonged stress willharm someone'ssondition, especially on elderly (Hamdiana, 2009).

In addition to the research conducted by Trisnapati (2012), there was also a study conducted by Nauli (2011) in his study stating that depression in the elderly in the intervention group atKatulampaVillage Bogor showed a significant decrease before and after logotherapy. Logotherapy has an effect on decreasing depression in the elderly with a decrease of $62.44 \%$. 


\section{Limitations of Research}

The limitation of the research wasduring data collection, a large number of female patients were not willing to be included in the study because of embarrassment and concern that the problem was known by others. In addition, the implementation ideally should be done in a comfortable place, but due to the limited space of the polyclinic, the implementation on several respondents was doneat the patient admission room so it did not provide peace for the respondents.

\section{CONCLUSIONS AND SUGGESTIONS} Conclusion

1. Cancer clientsat Ken Saras Hospital in Semarang Regency are mostly aged 36-45 years old as many as 14 people $(63.6 \%)$, highly educated $\mathrm{s}$ many as 15 people $(68.2 \%)$ and male as many as 14 people $(63.6 \%)$.

2. The level of depression in cancer clients before logotherapy at Ken Saras Hospital Semarang Regency is mostly in moderate depression, as many as 19 people $(86.4 \%)$.

3. The level of depression in cancer clients at Ken Saras Hospital Semarang Regency after logotherapy is mostly in mood disorders, as many as14 people (63.6\%).

4. There are differences in the level of depression before and after logotherapy in cancer clients at Ken Saras HospitalSemarang Regency, with $\mathrm{p}$ value $(0,000)<\alpha(0,05)$.

\section{Suggestion}

1. For Educational Institutions

NgudiWaluyo University should add literature related to logotherapy and make the results of this study as a basis for similar research, especially those related to logotherapy and depression.

2. For Hospitals

KenSaras Hospital Semarang Regency should use logotherapy as a complementary therapy to support the psychological side of cancer patients so that the healing process can run optimally.

3. For the next researcher

Further research should improve the results of this study by controlling other factors that influence the results of this study including limiting the duration of cancer patients to obtain more optimal research results.
4. For clients

Cancer patients who undergo treatment at Ken Saras HospitalSemarang Regency should optimize the use of logotherapy so that it can support the treatment process.

\section{REFERENCES}

Agnes, F. (2009). Effect of Logotherapy on Hypertension in The Elderly

Brunner \&Suddarth. (2008). Buku Ajar KeperawatanBedah, edisi 8, volume 3. Jakarta: EGC

Dattilio\&Ameli. (2013). Enhancing Cognitive Behavior Therapy With Logotherapy Techniques for Clinical Practice, Psychotherapy vol. 50.Diaksespada 10 maret 2017

Herawati, E. (2010). Keefektifan logo terapi terhadap penurunan intensitas nyeri pasien nyeri kronik di poliklinik rehabilitasi medic RSDM Surakarta

Kanine. E. (2011). Pengaruh Terapi Generali dan Logoterapi Individu Terhadap Respon Ketidakberdayaan Klien Diabetes Mellitus Di Rumah Sakit Provinsi Sulawesi Utara.

Kaplan \&Saccuzzo, D.P. (2012). Pengukuran Psikologis Prinsip, Penerapan, dan Isu. Jakarta: Salemba Humanika

Kelliat, B. Anna. 2016. Prinsip dan praktik keperawatan kesehatan jiwa stuart buku I. Edisi Indonesia. Singapore: Elsevier Singapore Pte Ltd

Kemenkes RI. (2015). Info DATIN Situasi Penyakit Kanker

Manurung, N. (2016). Terapi Reminiscence. Jakarta: CV. Trans Info Media

Maramis. 2008. Catatan Ilmu Kedokteran Jiwa. Surabaya: Airlangga. University Press

Mukwanto, dkk. (2010). Stress and Coping Mechanisms Among Breast Cancer Patients and Family. Diakses pada tanggal 10 Maret 2017 
Potter \& Perry. 2010. Fundamental Keperawatan buku 3. Edisi 7. Jakarta: Salemba Medika

Robatmili, S. (2014). The effect of group logoterapy on meaning in life and depression levels of Iranian student.

Smeltzer, S.C., \& Bare, B.G. (2008). Brunner \&Suddarth's:Texbook of medical surgical nursing. Philadelphia: Lippincott

Stuart \&Sunden. (2008). Buku Saku Keperawatan Jiwa. Jakarta: EGC

Stuart, G.W. (2009). Principles and practice of psychiatric nursing $\left(9^{\text {th }}\right.$ Edition). St Louis: Mosby

Sutejo. (2009). Pengaruh Logoterapi Kelompok Terhadap Ansietas Pada Penduduk pasca Gempa Di Kabupaten Klaten Propinsi Jawa Tengah.

Tobing. L. Duma (2012). Pengaruh progesif muscle relaxation dan logo terapi terhadap perubahan ansietas, depresi, kemampuan relaxasi dan kemampuan memaknai hidup klien kanker di RS Daharmais Jakarta

Videbeck, S.L. (2008). Buku ajar keperawatan jiwa. Jakarta: Penerbit Buku Kedokteran EGC.

World Health Organization (2005). World health statistics 2005. Diakses pada tanggal 10 Maret 2017

Yosep, I. (2014). Buku Ajar Keperawatan Jiwa edisi 6. Bandung: PT. RefikaAditam. 